\title{
A SOLAR EJECTOR COOLING SYSTEM USING REFRIGERANT R141b
}

\author{
B. J. HUANG ${ }^{\dagger}$, J. M. CHANG, V. A. PETRENKO and K. B. ZHUK \\ Department of Mechanical Engineering, National Taiwan University, Taipei 106, Taiwan
}

Received 8 October 1997; revised version accepted 14 July 1998

Communicated by BYARD WOOD

\begin{abstract}
A high-performance solar ejector cooling system using R141b as the working fluid was developed. We obtain experimentally a COP of 0.5 for a single-stage ejector cooling system at a generating temperature of $90^{\circ} \mathrm{C}$, condensing temperature of $28^{\circ} \mathrm{C}$, and an evaporating temperature $8^{\circ} \mathrm{C}$. For solar cooling application, an optimum overall COP can be obtained around 0.22 at a generating temperature of $95^{\circ} \mathrm{C}$, evaporating temperature of $8^{\circ} \mathrm{C}$ and solar radiation at $700 \mathrm{~W} \mathrm{~m}^{-2}$. (C) 1998 Elsevier Science Ltd. All rights reserved.
\end{abstract}

\section{INTRODUCTION}

A solar cooling/refrigeration system which converts the solar thermal energy into cooling effect has long been an interesting subject for scientists and engineers (Chinnapa, 1961; Kakabaev and Davletov, 1966; Anderson, 1975; Wilbur and Mancini, 1976; Stchetinina et al., 1987; Korres et al., 1989; Petrenko, 1992; Bansal et al., 1997). In practical application, a solar collector is used to absorb the solar thermal energy first. The heat is then used to drive a heat-driven cooling machine to produce a cooling effect.

The solar cooling system utilizing a $\mathrm{LiBr}-$ water or ammonia-water absorption cooling machine has been built frequently to demonstrate the application of solar cooling technology. However, the absorption cooling system utilizes a chemical absorption process and is thus quite complicated in design. Vacuum technology is also required for a $\mathrm{LiBr}$-water absorption system. High installation cost retards their application in solar cooling systems.

An ejector cooling system (ECS) can operate with low boiling point refrigerants as the working fluid and is known as one of the most promising devices for solar cooling/refrigeration applications. ECS is a mechanical system utilizing the Rankine cycle and the gas dynamic effect of ejector (a thermal compression process). The simplicity in design, high reliability and low installation cost makes the ECS more attractive than others. The only drawback of the ECS is its low COP, usually lower than 0.3 for a single-stage system (Jhadan et al., 1976; Huang et al., 1985;

$\dagger$ Author to whom correspondence should be addressed.
Petrenko, 1992; Eames et al., 1995a; Lallemand and Dorantes, 1995; Sun, 1996), while COP is around $0.4-0.6$ for a single-stage absorption cooling system (Wilbur and Mancini, 1976; Bansal et al., 1997). In the present study, we develop a solar ejector cooling system using R141b as the working fluid which can obtain a better COP than before.

\section{DESIGN OF A SOLAR EJECTOR COOLING SYSTEM}

Fig. 1 is the schematic of a single-stage solar ejector cooling system. The solar cooling system

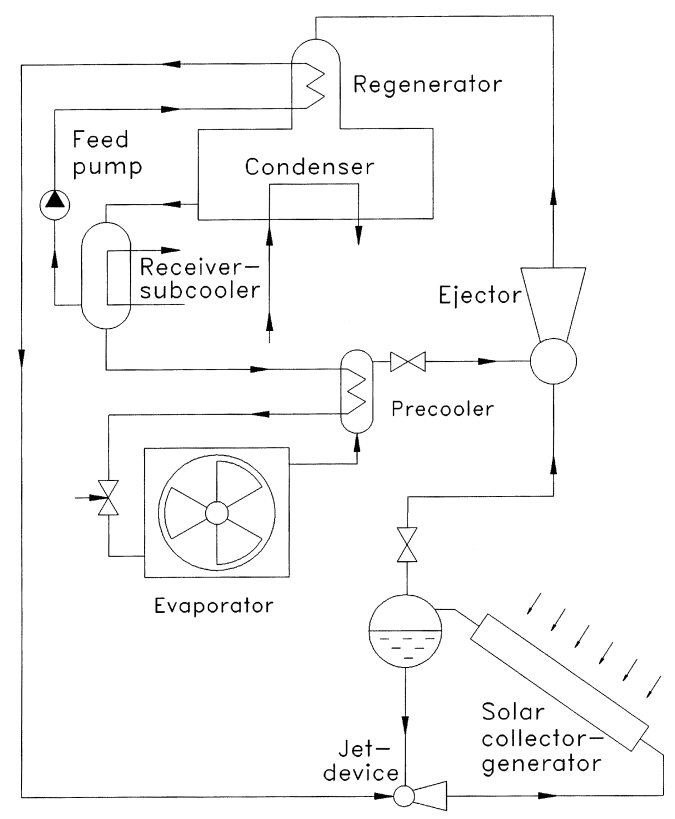

Fig. 1. Schematic diagram of a solar ejector cooling system. 
consists of only four major components: solar collector (generator), ejector, condenser/regenerator, evaporator. The solar collector acts as the generator of the ECS in which the working fluid is heated and evaporated. The mixing ejector is used here with the separator to re-circulate the liquid working fluid through the solar collector to enhance the boiling heat transfer.

In the present study, R141b is selected as the working fluid for the ejector cooling machine. $\mathrm{R} 141 \mathrm{~b}$ has a low boiling point $\left(32.07^{\circ} \mathrm{C}\right)$ and high performance according to Lallemand and Dorantes (1995).

We used a commercially-available doubleglazed selective-surface flat-plate solar collector as the generator. The energy collection efficiency of the collector is experimentally determined according to the modified ANSI/ASHRAE 931986 Standard (Huang and Hsieh, 1990):

$$
\eta_{\mathrm{sc}}=0.80-3.5 \frac{T_{\mathrm{i}}-T_{\mathrm{a}}}{I}
$$

where $I$ is the incident solar radiation $\left(\mathrm{W} \mathrm{m}^{-2}\right)$; $T_{\mathrm{i}}$ and $T_{\mathrm{a}}$ are the collector inlet and the ambient temperatures.

\section{PERFORMANCE ANALYSIS OF AN EJECTOR COOLING SYSTEM}

The ejector cooling system utilizes an ejector for vapor compression by use of the gas dynamic effect. For the ejector performance analysis, we developed an 1-D gas dynamic model which is similar to that of Eames et al. (1995b) but including the secondary flow choking phenomena proposed by Munday and Bagster (1976), (1977); Huang et al. (1985). The results are then used to evaluate the performance of a single-stage ejector cooling system.

The design specifications of the ejector are listed in Table 1. Fig. 2 shows that the COP of a single-stage ejector cooling system using R141b as the working fluid can reach as high as 0.6 at generation temperature $100^{\circ} \mathrm{C}$, condensing temperature $30^{\circ} \mathrm{C}$, and evaporating temperature $8^{\circ} \mathrm{C}$.

Table 1. Specifications of ejector

Primary flow nozzle:

Throat diameter, $\mathrm{mm}$

Exit diameter, $\mathrm{mm}$

Constant-area section:

Diameter, $\mathrm{mm}$

Diffuser angle, deg:

Distance between nozzle and

constant-area section, $\mathrm{mm}$ :

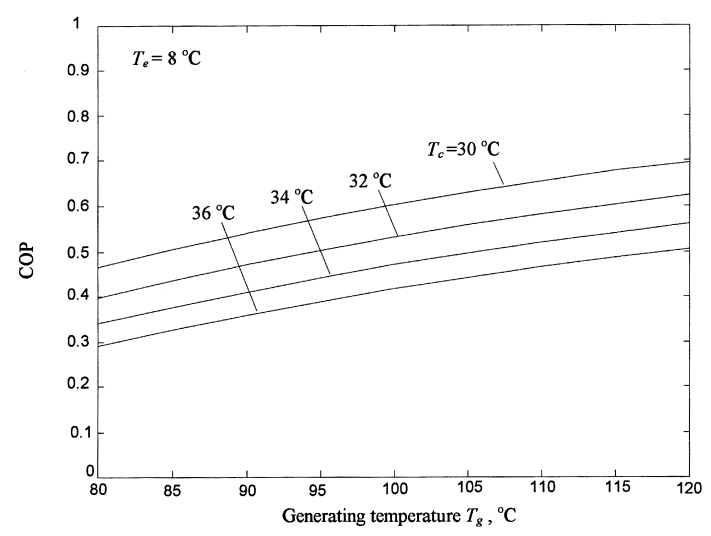

Fig. 2. Theoretical COP of a single-stage ejector cooling system.

The analytical results are experimentally verified and presented in Figs. 3 and 4.

The critical condensing temperature $T_{\mathrm{c}}^{*}$ is defined as the vapor saturation temperature corresponding to the critical back pressure of the ejector. For the back pressure of an ejector

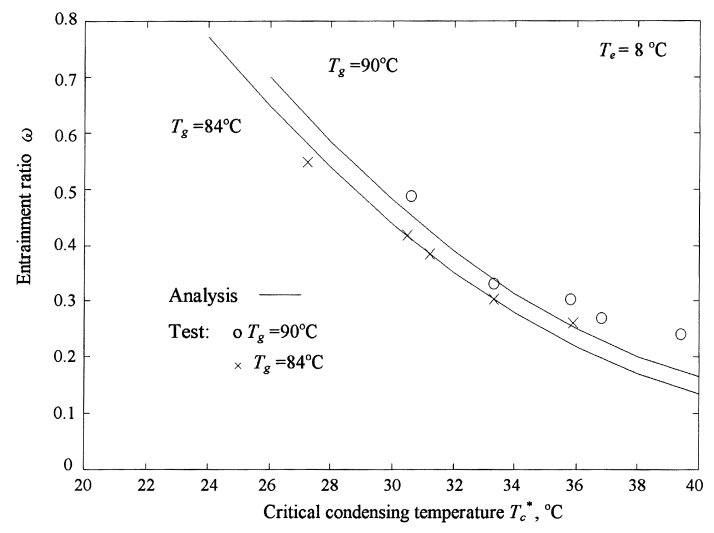

Fig. 3. Measured and computed ejector entrainment ratio.

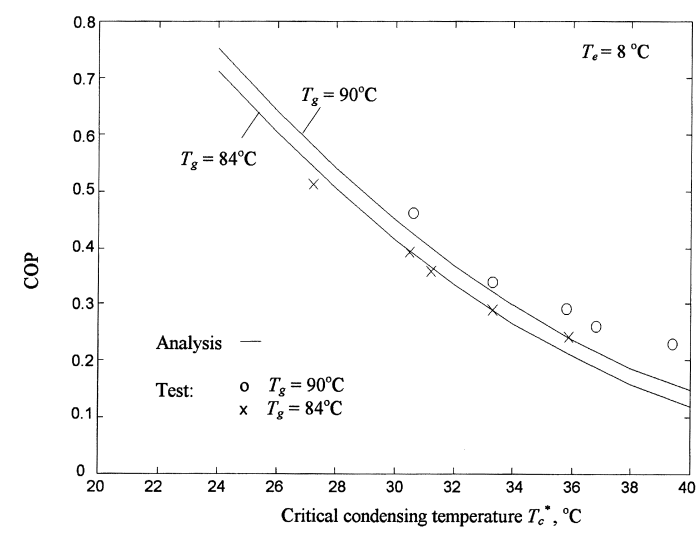

Fig. 4. Measured and computed COP of ejector cooling system. 
exceeding the critical back pressure, the choking of the secondary or suction flow will disappear and the ejector performance drops dramatically (Huang et al., 1985).

It is shown from Fig. 4 that the ejector cooling system designed in the present study has a very high COP. For a generating temperature of $90^{\circ} \mathrm{C}$, the $\mathrm{COP}$ reaches 0.5 at a condensing temperature of $28^{\circ} \mathrm{C}$ and evaporating temperature of $8^{\circ} \mathrm{C}$. This experimental result exceeds the published test data for freon ejector cooling systems.

The COP of the ECS can be improved further by properly selecting the generating temperature and using a better design of ejector. It can reach nearly 0.6 at generating temperature $100^{\circ} \mathrm{C}$, condensing temperature $30^{\circ} \mathrm{C}$, and evaporating temperature $8^{\circ} \mathrm{C}$ from the prediction of Fig. 2 .

\section{SOLAR EJECTOR COOLING SYSTEM PERFORMANCE}

The performance of the solar ejector cooling system can be analyzed by using the collector characteristics in Eq. 1, the 1-D ejector analysis (Fig. 2) and the testing results of the ejector cooling system. The overall system COP of the solar cooling system becomes:

$$
\mathrm{COP}_{\mathrm{o}}=\mathrm{COP}_{\mathrm{ECS}} \times \eta_{\mathrm{sc}}
$$

where $\mathrm{COP}_{\mathrm{ECS}}$ is the $\mathrm{COP}$ of the ejector cooling system presented in Fig. 2. We calculate the collector efficiency using the collector inlet temperature at $10^{\circ} \mathrm{C}$ higher than the generating temperature of the ejector cooling system, i.e. $T_{\mathrm{i}}=$ $T_{\mathrm{g}}+10^{\circ} \mathrm{C}$. Assuming no heat loss in the pipe, Fig. 5 shows that the system will have an optimum overall efficiency around 0.22 at $T_{\mathrm{g}}=95^{\circ} \mathrm{C}$ and $T_{\mathrm{e}}=8^{\circ} \mathrm{C}$, for solar radiation at $700 \mathrm{~W} \mathrm{~m}^{-2}$.

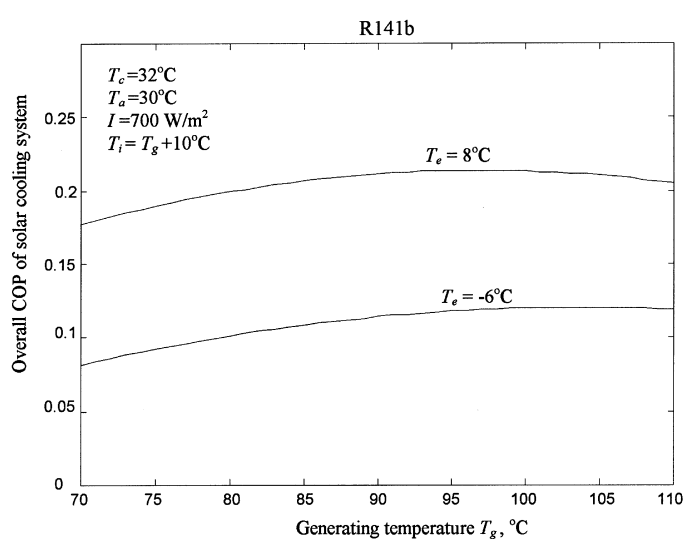

Fig. 5. Overall COP of a solar ejector cooling system.
The solar ejector cooling system can also become a refrigeration system if it was operated at low evaporating temperature. Fig. 5 shows that the solar refrigeration system has an optimum overall COP around 0.12 at $T_{\mathrm{i}}=102^{\circ} \mathrm{C}$ and $T_{\mathrm{e}}=$ $-6^{\circ} \mathrm{C}$ for solar radiation at $700 \mathrm{~W} \mathrm{~m}^{-2}$. This system can be used for an ice-storage air-conditioning system.

A solar refrigeration plant using the ejector cooling system is shown to be feasible according to the present study. A solar air-conditioning system is proposed according to the present results as follows:

Cooling capacity $10.5 \mathrm{~kW}(3 \mathrm{RT})$

Evaporating temperature $\quad 8^{\circ} \mathrm{C}$

Condensing temperature $\quad 32^{\circ} \mathrm{C}$

Generating temperature $\quad 95^{\circ} \mathrm{C}$

$\mathrm{COP}_{\mathrm{ECS}} \quad 0.5$

Solar collector eff. $\eta_{\mathrm{sc}} \quad 0.5$

$\mathrm{COP}_{\mathrm{o}} \quad 0.22$

Solar collector area $\quad 68 \mathrm{~m}^{2}$

In practical design, a backup heater which is driven by natural gas or oil is required at the exit of the solar collector. A compact, low-cost gasfired instant domestic water heater may be used with some simple temperature controller.

\section{DISCUSSIONS AND CONCLUSION}

The design of the solar ejector cooling system is very simple. By using the solar collector as the generator of the ejector cooling system, it has only four major components. The installation cost thus can be lowered as compared to the absorption cooling system. However, the performance of the ejector cooling system needs to be improved further in order to compete with the absorption system.

The performance of an ejector cooling system is affected by the working fluid selected, the ejector design and manufacturing, and the thermodynamic cycle design. In the present study, we use R141b as the working fluid and experimentally obtain a very high COP (about 0.5) for a single-stage ejector cooling system. If this was used in solar cooling, the overall COP of the solar ejector cooling system can reach as high as 0.22 . The solar cooling system can also be used for the ice-storage air-conditioning system if it was operated at low evaporating temperature $\left(-6^{\circ} \mathrm{C}\right)$.

The research on the ejector cooling system is still underway at the National Taiwan University. The final goal is to improve the COP of the 
ejector cooling system to about 0.7 so that it can compete with the absorption cooling system. This is possible based on the present and some other recent studies (Eames et al., 1995a,b; Nahdi et al., 1993). The ejector cooling system can also be driven by various kinds of energy sources such as solar, waste heat, bio-gas energy, natural gas, or oil etc.

\section{NOMENCLATURE}

\begin{tabular}{|c|c|}
\hline $\mathrm{COP}_{\mathrm{ECS}}$ & $\begin{array}{l}\text { Coefficient of performance (COP) of the ejector } \\
\text { cooling system, dimensionless }\end{array}$ \\
\hline $\mathrm{COP}_{\mathrm{o}}$ & $\begin{array}{l}\text { Overall coefficient of performance (COP) of solar } \\
\text { ejector cooling system, } \\
\text { dimensionless }\end{array}$ \\
\hline$I$ & $\begin{array}{l}\text { Solar radiation incident upon the collector slope, } \\
\mathrm{W} \mathrm{m}^{-2}\end{array}$ \\
\hline$T_{\mathrm{a}}$ & Ambient temperature, ${ }^{\circ} \mathrm{C}$ \\
\hline$T_{\mathrm{c}}^{*}$ & $\begin{array}{l}\text { Vapor saturation temperature corresponding to the } \\
\text { critical back pressure of ejector, }{ }^{\circ} \mathrm{C}\end{array}$ \\
\hline$T_{\mathrm{e}}$ & $\begin{array}{l}\text { Evaporating temperature of ejector cooling sys- } \\
\text { tem, }{ }^{\circ} \mathrm{C}\end{array}$ \\
\hline$T_{\mathrm{g}}$ & $\begin{array}{l}\text { Generating temperature of ejector cooling system, } \\
{ }^{\circ} \mathrm{C}\end{array}$ \\
\hline$T_{\mathrm{i}}$ & Collector inlet temperature, ${ }^{\circ} \mathrm{C}$ \\
\hline$\eta_{\mathrm{sc}}$ & Solar collector efficiency, dimensionless \\
\hline$\omega$ & $\begin{array}{l}\text { Ejector entrainment ratio (= primary flowrate } / \text { suc }- \\
\text { tion flowrate) }\end{array}$ \\
\hline
\end{tabular}

Acknowledgements-The present study was supported by the National Science Council, Taiwan, through Grant No. NSC862212-E002-088 and NSC86-2811-E002-004R and the Energy Commission, the Ministry of Economic Affairs, Taiwan, ROC.

\section{REFERENCES}

Anderson H. (1975) Assessment of solar powered vapor jet air-conditioning systems. Proc. 1975 ISES Congress, Los Angeles, CA, USA, July 28-August 1, 1975.

Bansal N. K., Blumenberg J., Kavasch H. J. and Roettinger T. (1997) Performance testing and evaluation of solid absorption solar cooling unit. Solar Energy 61, 2, 127-140.

Chinnapa J. C. V. (1961) Experimental study of the intermittent vapor absorption refrigeration cycle employing the refrigerant-absorbent systems of ammonia water and ammonia lithium nitrate. Solar Energy 5, 1-18.

Eames I. W., Aphornratana S. and Sun D.-w. (1995) The jet-pump cycle - a low cost refrigerator option powered by waste heat. Heat Recovery Systems and CHP 15, 8, 711721.

Eames I. W., Aphornratana S. and Haider H. (1995) A theoretical and experimental study of a small-scale stem jet refrigerator. Int. J. Refrig. 18, 6, 378-386.

Huang B. J. and Hsieh S. W. (1990) An automation of collector testing and modification of ANSI/ASHRAE 931986 Standard ASME. J. Solar Energy Eng. 112, 257-267.

Huang B. J., Jiang C. B. and Hu F. L. (1985) Ejector performance characteristics and design analysis of jet refrigeration system. Trans ASME J. Eng. Power 107, 792-802.

Jhadan S. Z., Petrenko V. A., Kitaev V. F. and Vasiliev J. Z. (1976) Investigation of the ejector refrigeration machine using R142b at the operating conditions. Kholodilnaya Technicai I technologia, Kiev, Technica, 3-7.

Kakabaev A. and Davletov A. (1966) A freon ejector solar cooler. Geliotekhnika 2, 5, 42-48.

Korres C. J., Bardakas E. E. and Koumou-tsos N. G. (1989) Performance analysis of a solar vapour thermal compression chiller. Int. J. Energy Res. 13, 243-252.

Lallemand R. and Dorantes A. (1995) Prediction of performance of a jet cooling system operating with pure refrigerants or non-azeotropic mixtures. Int. J. Refrig. 18, 1, 21-30.

Munday J. T. and Bagster D. F. (1976) The choking phenomena in ejector with particular reference to steam jet refrigeration. Thermal fluids Conference of Inst. of Eng. Australia, Hobart, National Conference Publication, pp. 84-88, 1976.

Munday J. T. and Bagster D. F. (1977) A new ejector theory applied to steam jet refrigeration. Ind. Eng. Chem. Process Des. Dev. 16, 4, 442-449.

Nahdi E., Champoussin J. C., Hostache G. and Cheron J. (1993) Optimal geometric parameters of a cooling ejectorcompressor. Int. J. Refrig. 16, 1, 67-72.

Petrenko V. A. (1992) A solar vapor ejector refrigerator testing in air conditioning regime. World Renewable Energy Congress, Reading, UK, Sept. 13-18, 1992.

Stchetinina N. A., Jhadan S. Z. and Petrenko V. A. (1987) Comparison between the efficiency of different types of heating for solar ejector freon refrigeration machine generator. Heliotechnica N4, 71-74.

Sun D.-w. (1996) Variable geometry ejectors and their applications in ejector refrigeration systems. Energy 21, 10, 919929.

Wilbur P. J. and Mancini T. R. (1976) A comparison of solar absorption air conditioning systems. Solar Energy 18, 569. 